\title{
Pengaruh Model Kooperatif Tipe Think Pair Share terhadap Hasil Belajar Tematik Terpadu di Sekolah Dasar
}

\author{
Orina Sandrika Murti ${ }^{1}$, Reinita ${ }^{2}$ \\ Pendidikan Guru Sekolah Dasar, Universitas Negeri Padang, Indonesia \\ Email: orinasandd@gmail.com ${ }^{1)}$ reinita reinita@yahoo.com ${ }^{2)}$
}

\begin{abstract}
Abstrak
Tujuan penelitian ini dilatarbelakangi untuk mengetahui pengaruh model kooperatif tipe Think Pair Share terhadap hasil belajar siswa di kelas V SDN Gugus III Kecamatan Ranah Pesisir. Jenis penelitian kuantitatif dalam bentuk quasi eksperimen design dengan tipe Nonequivalent control group design. Teknik pengambilan sampel purposive sampling, populasi terdiri dari SD dalam Gugus III Kecamatan Ranah Pesisir, sampel yang terpilih adalah kelas V SDN 05 Koto VIII Mudik sebagai kelas eksperimen dan SDN 02 Koto Nan IV sebagai kelas kontrol. Instrument yang digunakan adalah tes objektif dengan jenis pilihan ganda. Hasil penelitian diperoleh rata-rata kelas eksperimen 81,94 dan rata-rata kelas kontrol 69,75. Perhitungan uji-t ( $t$-test) diperoleh $t_{\text {hitung }} 3,51$ sedangkan tabel pada taraf kepercayaan a 0,05 adalah 2,028 sehingga $t_{\text {hitung }}>t_{\text {tabel. }}$. Disimpulkan bahwa terdapat pengaruh positif dan signifikan penggunaan model kooperatif tipe Think Pair Share terhadap hasil belajar siswa pada pembelajaran tematik terpadu kelas V SDN Gugus III kecamatan Ranah Pesisir.
\end{abstract}

Kata Kunci: Think Pair Share, Hasil Belajar, Tematik Terpadu.

\begin{abstract}
Abstarct
The purpose of this study was motivated to determine the effect of the Think Pair Share type cooperative model on student learning outcomes in class V SDN Gugus III District Ranah Pesisir. This type of quantitative research is in the Form of a quasi-experimental design with the Nonequivalent control group design type. The sampling technique was purposive sampling, the population consisted of SD in Cluster III Ranah Pesisir District, the selected sample was class V SDN 05 Koto VIII Mudik as the experimental class and SDN 02 Koto Nan IV as the control class. The instrument used was an objective test with multiple choice types. The results of the study obtained an average of 81.94 for the experimental class and 69 for the control class. The t-test calculation obtained t-test 3.51 while t-table at the $\alpha 0.05$ level was 2.028 so that tcount> ttable. It is concluded that there is a positive and significant effect of the use of the Think Pair Share cooperative model on student learning outcomes in integrated thematic learning in class V SDN Gugus III, Ranah Pesisir sub-district.
\end{abstract}

\section{Keywords: Think Pair Share, Learning Outcomes, Integrated Thematic.}

\section{PENDAHULUAN}

Model pembelajaran merupakan rancangan yang digunakan guru sebagai pedoman dalam proses pembelajaran sehingga pembelajaran dapat terlaksana sesuai dengan yang diharapkan. Menurut Afandi, Chamalah dan Wardani (2013:16) Model pembelajaran adalah prosedur atau pola sistematis yang digunakan sebagai pedoman untuk mencapai tujuan pembelajaran didalamnya terdapat strategi, teknik, metode, bahan, media dan alat penilaian pembelajaran.

Model pembelajaran merupakan salah satu hal yang penting dalam penerapan Kurikulum 2013, tepatnya dalam pembelajaran tematik terpadu. Dalam pembelajaran tematik terpadu guru hendaknya mampu menciptakan pembelajaran yang menarik dan menyenangkan, sehingga dapat memunculkan minat dan semangat siswa dalam belajar. 
Sesuai dengan pendapat (Reinita, 2019) yang menyatakan bahwa "Indonesian Government Regulation Number 19 of 2005 concerning National Education Standards shows that teachers must play an active role as subjects of education who always increase innovation and creativity in the learning process". Artinya, Peraturan Pemerintah Indonesia Nomor 19 Tahun 2005 mengenai Standar Pendidikan Nasional menunjukkan bahwa guru harus memainkan peran aktif sebagai subjek dari pendidikan yang selalu meningkatkan inovasi dan kreativitas dalam proses pembelajaran. Caranya adalah dengan menerapkan model pembelajaran yang dapat membangkitkan minat siswa dalam belajar sehingga siswa menjadi aktif dalam proses pembelajaran sehingga tujuan pembelajaran dapat tercapai. Sesuai dengan pendapat (Reinita, Suarman, \& Sakdiyah, 2020) "the selection of an appropriate learning model during the learning process is something that can support the learning objectives to be achieved". Artinya, pemilihan model pembelajaran yang tepat selama proses pembelajaran adalah sesuatu yang dapat mendukung tujuan pembelajaran yang ingin dicapai. Salah satunya adalah model Kooperatif tipe Think Pair Share (TPS).

Model Pembelajaran Kooperatif Tipe Think Pair share (TPS) merupakan model pembelajaran yang dirancang untuk mempengaruhi pola interaksi siswa. Lestari dan Yudhanegara (2017:52) mengatakan bahwa "TPS merupakan salah satu tipe pembelajaran kooperatif yang merangsang aktivitas berfikir siswa secara berpasangan dan berbagi pengetahuan kepada siswa lainnya".

Menurut Taufik, Taufina dan Muhammadi (2012) langkah-langkah model pembelajaran Think Pair Share (TPS) adalah: 1) Think, dimana siswa diminta untuk berfikir secara mandiri tentang materi/permasalahan yang diberikan oleh guru, 2) Pair, siswa diminta untuk berpasangan dengan teman sebelahnya (kelompok 2 orang) dan saling berbagi fikirannya masing-masing, dan 3) Share, guru meminta pasangan-pasangan tersebut untuk membagikan hasil diskusinya di depan kelas.

(Reinita, dan D. A, 2019) menyatakan bahwa "Model kooperatif TPS dapat mengoptimalkan hasil belajar siswa setelah proses pembelajaran dilaksanakan karena siswa aktif dalam berfikir". Model Kooperatif tipe Think Pair Share (TPS) juga dapat meningkatkan kerjasama siswa dalam proses pembelajaran, serta dapat meningkatkan kemampuan siswa dalam mengemukakan pendapat.. Hal tersebut sesuai dengan pendapat Shoimin (2014) yang mengatakan kelebihan dari model Think Pair Share (TPS) adalah 1) mudah diterapkan dalam setiap jenjang pendidikan dan dalam setiap kesempatan yang ada, 2) memberikan waktu kepada siswa untuk berfikir, 3) membuat siswa lebih aktif dalam berfikir mengenai konsep dalam mata pelajaran, 4) selama diskusi, siswa lebih paham akan konsep yang dibahas, 5) siswa dapat belajar dari temannya, 6) kesempatan yang sama bagi setiap siswa untuk menyampaikan pendapat.

Kenyataan yang peneliti temukan di lapangan pada saat melakukan observasi pada tanggal 31 Agustus s/d 5 September 2020 di kelas V SDN Gugus III Kecamatan Ranah Pesisir adalah pembelajaran tematik terpadu kurang terlaksana dengan baik sebagaimana mestinya. Peneliti menemukan bahwa siswa kurang dilibatkan secara langsung dalam penemuan suatu konsep pembelajaran, siswa kurang dituntut untuk menyelesaikan masalah/persoalan secara individu, serta siswa kurang berkolaborasi untuk menyampaikan pendapatnya, serta banyak siswa yang sibuk dengan kegiatannya sendiri pada saat pembelajaran berlangsung. Model pembelajaran yang digunakan masih menggunakan model pembelajaran konvensional yang pada pelaksanaannya didominasi oleh guru. Hal ini sesuai dengan pendapat (Reinita, Miaz, \& Waldi, 2019) yang menyatakan bahwa "The conventional learning model used today is lecturing in which the teacher is more active than the students". Artinya, model pembelajaran konvensional yang digunakan saat ini adalah mengajar di mana guru lebih aktif daripada siswa. Hal ini berdampak pada kurangnya pemahaman siswa terhadap materi yang diajarkan dan berujung pada rendahnya hasil belajar yang diperoleh. (Astimar \& Indrawati, 2014) mengatakan bahwa "Hasil belajar merupakan tolak ukur yang digunakan untuk menentukan tingkat keberhasilan siswa dalam memahami konsep dalam belajar". 
Kenyataan di lapangan ini memerlukan perbaikan dengan menggunakan model pembelajaran yang diterapkan dalam pembelajaran termatik terpadu. Salah satunya adalah Tipe Think Pair Share (TPS) karena dalam pelaksanaannya model ini relatif lebih sederhana dan terdapat kelebihan yang memungkinkan siswa untuk berpikir kritis, bekerja sama dan memiliki kesempatan untuk menyampaikan pendapatnya.

Berdasarkan paparan di atas, diperlukan suatu penelitian untuk mengetahui pengaruh penggunaan model Kooperatif Tipe Think Pair Share (TPS) terhadap hasil belajar pada pembelajaran tematik terpadu. Peneliti mengambil judul "Pengaruh Model Kooperatif Tipe Think Pair Share (TPS) terhadap Hasil Belajar Siswa pada Pembelajaran Tematik Terpadu Kelas V SDN Gugus III Kecamatan Ranah Pesisir".

\section{METODE PENELITIAN}

Penelitian ini merupakan penelitian eksperimen. Jenis penelitian ini adalah penelitian kuantitatif. Arikunto (2014) menyatakan bahwa penelitian kuantitatif adalah penelitian yang menggunakan angka mulai dari pengumpulan data, penafsiran terhadap data yang telah dikumpulkan dan penampilan hasilnya. Desain yang digunakan adalah Quasi Experimental Design. Rancangan penelitian yang digunakan adalah nonequivalent control group design. Penelitian ini didesain menjadi dua kelas yaitu kelas eksperimen dan kelas kontrol. Kelas eksperimen diberi perlakuan dengan mengunakan model pembelajaran Think Pair Share (TPS) sedangkan kelas kontrol menggunakan pembelajaran konvensional. Sebelum diberi perlakuan, kelas sampel diberi pre-test terlebih dahulu untuk mengetahui kemampuan awal siswa. Setelah diberi perlakuan, selanjutnya diberikan post-test kepada kedua sampel untuk melihat ada tidaknya pengaruh model Think Pair Share (TPS) terhadap hasil belajar siswa.

Populasi pada penelitian ini adalah seluruh siswa di kelas V SDN Gugus III Kecamatan Ranah Pesisir yang terdiri dari 5 sekolah pada semester ganjil tahun ajaran 2020/2021. Teknik pengambilan sampel yang digunakan adalah Nonprobability Sampling. Teknik nonprobability sampling yang digunakan adalah purposive sampling. Pada teknik purposive sampling ini, sampel sengaja dipilih berdasarkan karakteristik dan pertimbangan tertentu. Langkah-langkah dalam pengambilan sampel pada penelitian ini adalah sebagai berikut: 1) mengumpulkan data nilai PH Tema 3 Sub Tema 2,2) menghitung rata-rata nilai, 3) melakukan uji normalitas dan uji homogenitas populasi, 4) setelah didapat hasil uji normalitas dan uji homogenitas, maka dilanjutkan dengan memilih SD dengan kriteria berikut: (a) jarak sekolah yang berdekatan sehingga dapat menghemat waktu dan biaya, dari 5 sekolah tersebut yang masuk kriteria ialah SDN 02 Koto Nan IV, SDN 05 Koto VIII Mudik, SDN 22 Palangai Gadang dan SDN 24 Koto VIII Mudik, (b) jumlah siswa yang genap, karena disini peneliti menggunakan kelompok berpasangan, dan sekolah yang memenuhi kriteria ini adalah SDN 02 Koto Nan IV, SDN 05 Koto VIII Mudik, dan SDN 24 Koto VIII Mudik, (c) selisih jumlah siswa yang tidak terlalu jauh, sehingga SDN 24 Koto VIII Mudik tidak bisa digunakan sebagai sampel karena jumlah siswanya hanya 6 orang, 5) berdasarkan pertimbangan yang telah peneliti uraikan di atas, sampel dalam penelitian ini adalah SDN 02 Koto Nan IV dan SDN 05 Koto VIII Mudik. Maka ditentukan bahwa yang menjadi kelas eksperimen adalah SDN 05 Koto VIII Mudik dan yang menjadi kelas kontrolnya adalah SDN 02 Koto Nan IV.

Metode pengumpulan data yang digunakan adalah tes hasil belajar tematik terpadu. Uji coba instrumen tes yang digunakan yaitu uji validitas dengan menggunakan rumus korelasi product moment, uji reliabilitas dengan menggunakan rumus Spearman-Brown, uji daya pembeda soal dan indeks kesukaran soal. Analisis data menggunakan uji prasyarat analisis, dan uji hipotesis. Uji prasyarat analisis meliputi uji normalitas dengan metode liliefors dan uji homogenitas dengan metode uji fisher. Sedangkan untuk menguji hipotesis digunakan uji $\mathrm{t}(\mathrm{t}$-test). 


\section{HASIL DAN PEMBAHASAN \\ Deskripsi Data Pre-test}

Data pretest diperoleh dari tes awal sebelum diberikan pembelajaran menggunakan model Kooperatif Tipe TPS pada kelas eksperimen, dan kelas kontrol menggunakan model Konvensional. Pembelajaran yang dilakukan adalah Tema 4 Sub Tema 1 Pembelajaran 3 dan 4. Nilai pre-test kelas eksperimen dan kelas kontrol dapat dilihat pada tabel 1, berikut:

\section{Tabel 1. Deskripsi Data Hasil Pre-test Kelas Eksperimen dan Kelas Kontrol}

\begin{tabular}{ccc}
\hline Variabel & \multicolumn{2}{c}{ Pre-test } \\
\cline { 2 - 3 } & Kelas eksperimen & Kelas kontrol \\
\hline $\mathbf{N}$ & 18 & 20 \\
\hline Nilai Tertinggi & 75 & 80 \\
\hline Nilai Terendah & 25 & 30 \\
\hline Mean/Rata-Rata & 53,61 & 55,50 \\
\hline Standar Deviasi & 14,22 & 14,68 \\
\hline Varians & 202,20 & 215,50 \\
\hline
\end{tabular}

Berdasarkan tabel diatas, kelas eksperimen dengan jumlah anak 18 orang memperoleh nilai tertinggi 75 dan nilai terendah 25. Dari nilai kelas eksperimen diperoleh rata-rata nilai sebesar 53,61, standar deviasi 14,22 dan nilai varians 202,20 . Sedangkan kelas kontrol dengan jumlah anak 20 orang memperoleh nilai tertinggi 80 dan nilai terendah 30. Dari nilai kelas kontrol diperoleh rata-rata nilai sebesar 55,50, standar deviasi 14,68 dan nilai varians 215,50 .

Hal ini menunjukkan bahwa hasil belajar kelas eksperimen lebih rendah dibandingkan dengan kelas kontrol. Untuk lebih jelasnya dapat dilihat pada gambar di bawah ini:

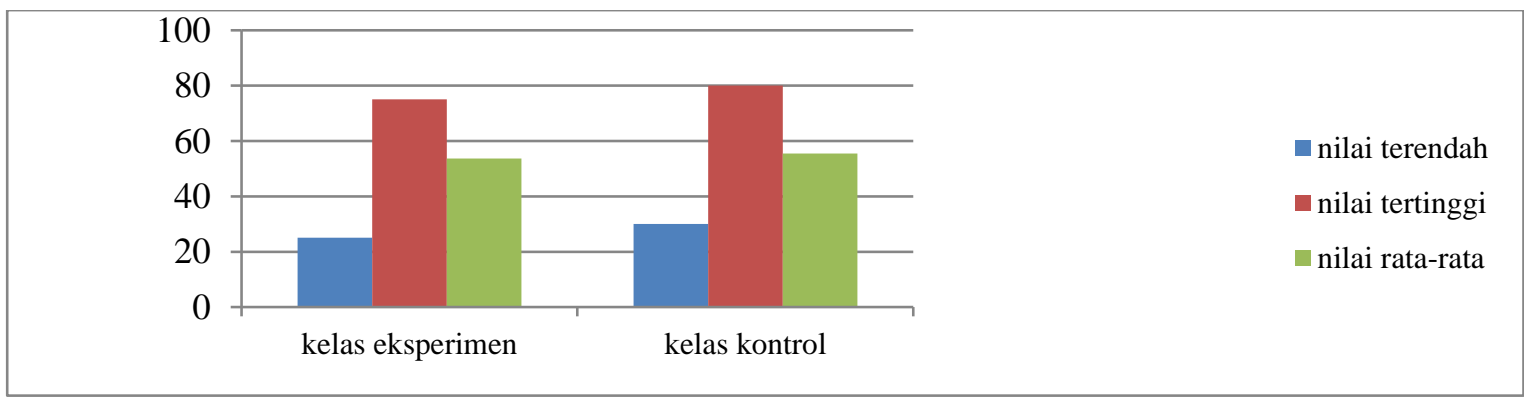

Gambar 1. Grafik perbandingan hasil pre-test kelas eksperimen dan kelas kontrol

\section{Deskripsi Data Post-test}

Data Post-test diperoleh dari tes akhir setelah diberikan pembelajaran menggunakan model Kooperatif Tipe Think Pair Share (TPS) pada kelas eksperimen, dan kelas kontrol menggunakan model pembelajaran Konvensional. Nilai Post-test kelas eksperimen dan kelas kontrol dapat dilihat pada tabel 2, berikut:

Tabel 2. Deskripsi Data Hasil Post-test Kelas Eksperimen dan Kelas Kontrol

\begin{tabular}{ccc}
\hline \multirow{2}{*}{ Variabel } & \multicolumn{2}{c}{ Post-test } \\
\cline { 2 - 3 } & Kelas eksperimen & Kelas kontrol \\
\hline $\mathbf{N}$ & 18 & 20 \\
\hline Nilai Tertinggi & 100 & 95 \\
\hline Nilai Terendah & 65 & 55 \\
\hline Mean/Rata-Rata & 81,94 & 69,75 \\
\hline Standar Deviasi & 11,52 & 9,93 \\
\hline Varians & 132,71 & 98,60
\end{tabular}


Berdasarkan tabel 2, kelas eksperimen dengan jumlah anak 18 orang memperoleh nilai tertinggi 100 dan nilai terendah 65. Dari nilai kelas eksperimen diperoleh rata-rata nilai sebesar 81,94, standar deviasi 11,52 dan nilai varians 132,71. Sedangkan kelas kontrol dengan jumlah anak 20 orang memperoleh nilai tertinggi 95 dan nilai terendah 55 . Dari nilai kelas kontrol diperoleh rata-rata nilai sebesar 69,75, standar deviasi 9,93 dan nilai varians 98,60 .

Hal ini menunjukkan bahwa hasil belajar kelas eksperimen lebih tinggi dibandingkan dengan kelas kontrol. Untuk lebih jelasnya dapat dilihat pada gambar berikut:

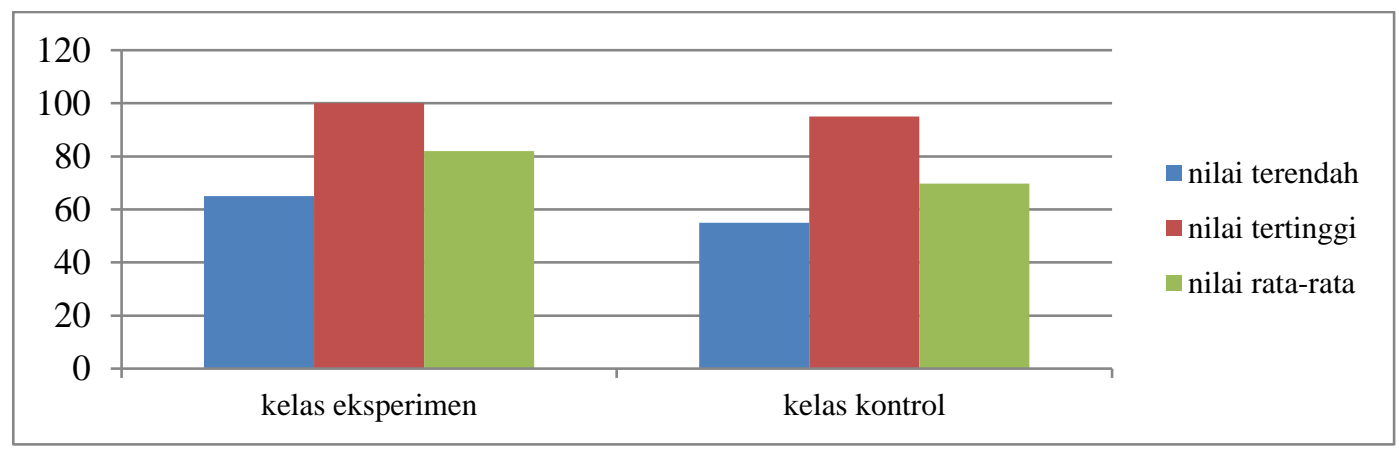

Gambar 2. Grafik perbandingan hasil post-test kelas eksperimen dan kelas control

Selanjutnya berdasarkan pengukuran pre-test dan post-test kelas eksperimen dan kelas kontrol, terdapat perbedaan antar kedua kelas. Perbedaan nilai pre-test dan nilai posttest antara kelas eksperimen dan kelas kontrol dapat dilihat pada tabel berikut:

Tabel 3. Perbandingan nilai pretest dan posttest antara kelas eksperimen dan kontrol

\begin{tabular}{ccccc}
\hline \multirow{2}{*}{ No } & \multirow{2}{*}{ Kelas } & \multicolumn{2}{c}{ Nilai rata-rata } & Peningkatan \\
\cline { 3 - 5 } & & Pretest & Posttest & \\
\hline 1. & Eksperimen & 53,61 & 81,94 & 28,33 \\
\hline 2. & Kontrol & 55,50 & 69,75 & 14,25 \\
\hline
\end{tabular}

Berdasarkan tabel diatas perbandingan nilai pre-test dan post-test kelas eksperimen dan kelas kontrol diatas dapat disajikan pada gambar berikut:

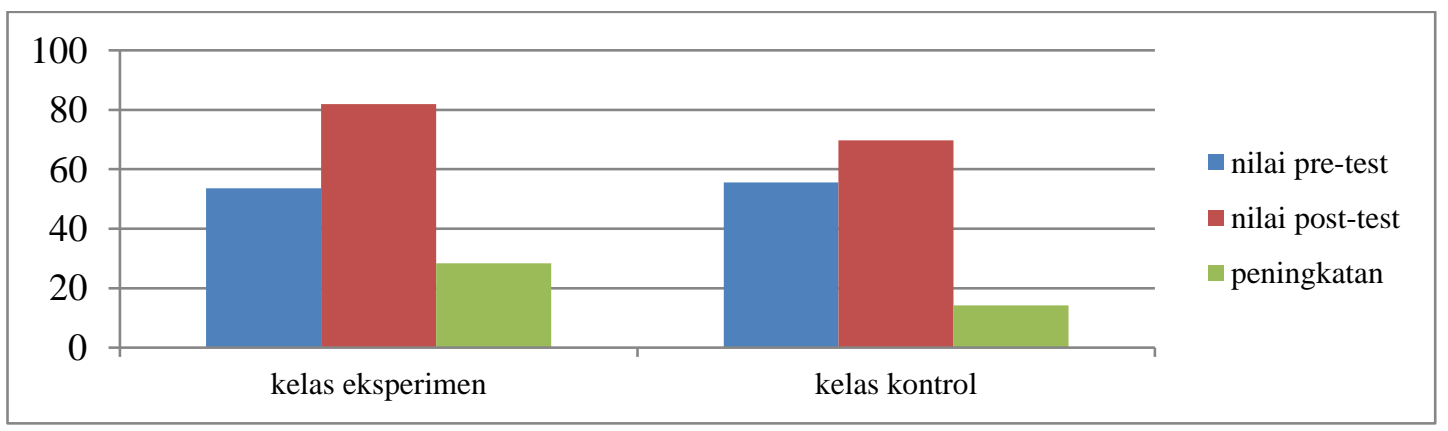

\section{Gambar 3. Grafik perbandingan hasil pre-test dan post-test kelas eksperimen dengan kelas kontrol}

Berdasarkan analisis data pre-test dan post-test hasil belajar kelas eksperimen dan kelas kontrol, terdapat perbedaan perolehan nilai hasil belajar antara kedua kelas. Peningkatan nilai kelas eksperimen lebih tinggi dari nilai kelas kontrol. Hal ini menunjukkan bahwa pembelajaran menggunakan model Kooperatif Tipe Think Pair Share (TPS) dapat 
memberikan pengaruh yang lebih baik dibandingkan dengan model pembelajaran Konvensional.

\section{Uji Prasyarat Analisis \\ Uji Normalitas}

Uji normalitas dengan menggunakan uji Liliefors untuk menguji apakah data pre-test dan post-test kedua kelas sampel yang diperoleh berasal dari data yang berdistribusi normal atau tidak pada taraf signifikasi $\alpha=0.05$. Berikut tabel 4 adalah hasil perhitungan $U j \mathrm{ji}$ normalitas dengan kriteria jika $L_{0}<L_{t}$ artinya data berdistribusi normal.

Tabel 4. Hasil uji normalitas data

\begin{tabular}{ccccc}
\hline \multirow{2}{*}{$\begin{array}{c}\text { Aspek yang } \\
\text { diamati }\end{array}$} & \multicolumn{2}{c}{ Eksperimen } & \multicolumn{2}{c}{ Kontrol } \\
\cline { 2 - 5 } & Pre-test & Post-test & Pre-test & Post-test \\
\hline $\mathrm{L}_{0}$ & 0.1069 & 0,1158 & 0,1120 & 0,1481 \\
\hline $\mathrm{L}_{t}$ & 0.200 & 0.200 & 0,190 & 0.190 \\
\hline Kesimpulan & $\mathrm{L}_{0}<\mathrm{L}_{t}$ & $\mathrm{~L}_{0}<\mathrm{L}_{t}$ & $\mathrm{~L}_{0}<\mathrm{L}_{t}$ \\
\hline Keterangan & \multicolumn{3}{c}{ Data Berdistribusi Normal } \\
\hline
\end{tabular}

Berdasarkan tabel tersebut diperoleh hasil bahwa pada kelas eksperimen menunjukkan $L_{0}$ data pre-test dan post-test $(0,1069$ dan 0,1158$)$ lebih kecil dari $L_{\text {tabel }}(0,200)$ $(\mathrm{n}=18,=0,05)$ dan kelas kontrol menunjukkan $\mathrm{L}_{0}$ data pre-test dan post-test $(0,1120$ dan $0,1481)$ lebih kecil dari $\mathrm{L}_{\text {tabel }}(0,190)(\mathrm{n}=20,=0,05)$ dan dapat disimpulkan bahwa data pretest dan post-test kedua kelas berdistribusi normal.

\section{Uji Homogenitas}

Uji homogenitas menggunakan uji $\mathrm{F}$ yang bertujuan untuk melihat data pre-test dan post-test dari kedua kelas memiliki variansi yang homogen/tidak. Hasil pengujian homogenitas dapat dilihat pada tabel dibawah ini.

Tabel 5. Hasil Uji Homogenitas Data

\begin{tabular}{ccc}
\hline Aspek yang diamati & Pre-test & Post-test \\
\hline$F_{\text {hitung }}$ & 1,065 & 1,346 \\
\hline$F_{\text {tabel }}$ & 2,24 & 2,20 \\
\hline Kesimpulan & \multicolumn{2}{c}{ F hitung $^{<}$F $_{\text {tabel }}$} \\
\hline Keterangan & \multicolumn{2}{c}{ Data Bervarians Homogen } \\
\hline
\end{tabular}

Perhitungan harga $\mathrm{F}$ dengan taraf signifikan 0,05 dari tabel distribusi $\mathrm{F}$ ternyata diperoleh $F_{\text {hitung }}$ pretest sebesar 1,065 dan $F_{\text {tabel }}$ sebesar 2,24 maka $F_{\text {hitung }}<F_{\text {tabel. }}$. Dan untuk

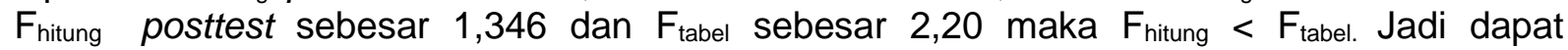
disimpulkan bahwa data pretest dan data posttest memiliki distribusi data yang homogen.

\section{Uji Hipotesis}

\section{Uji Hipotesis Posttest}

Berikut hasil perhitungan uji-t data posttest dari kedua kelas sampel.

Tabel 6. Hasil Uji Hipotesis Posttest (uji-t)

\begin{tabular}{ccc}
\hline Ket & \multicolumn{3}{c}{ Posttest } \\
\hline Kelas & Eksperimen & Kontrol \\
\hline $\mathbf{N}$ & 18 & 20 \\
\hline Rata-rata & 81,94 & 69,75 \\
\hline $\mathbf{t}_{\text {hitung }}$ & \multicolumn{3}{c}{3,51} \\
\hline $\mathbf{t}_{\text {tabel }}$ & \multicolumn{3}{c}{2,028} \\
\hline Kesimpulan & \multicolumn{2}{c}{ Terdapat Pengaruh } \\
\hline
\end{tabular}


Dari hasil uji t tersebut diperoleh nilai thitung untuk nilai posttest $=3,51$ dan $t_{\text {tabel }}=2,028$ dengan taraf signifikasi 0.05 dan derajat kebebasan $(\mathrm{df} / \mathrm{db}=18+20-2=36$ ) ini menunjukan bahwa thitung $>t_{\text {tabel }}$ atau 3,51 > 2,028 dengan demikian maka $\mathrm{H}_{0}$ ditolak, $\mathrm{H}_{1}$ diterima maka dapat dikatakan bahwa data posttest atau tes akhir menunjukan adanya pengaruh pada model Kooperatif Tipe Think Pair Share (TPS) yang digunakan dalam penelitian ini.

\section{Pembahasan}

Hasil penelitian menunjukkan bahwa adanya pengaruh antara penggunaan model Kooperatif Tipe Think Pair Share (TPS) dengan penggunaan model pembelajaran konvensional terhadap hasil belajar tematik terpadu. Terbukti dengan hasil uji hipotesis yang menyatakan menolak $\mathrm{H}_{0}$ pada taraf signifikansi $5 \%$. Peneliti menggunakan pretest dan posttest untuk mengetahui kemampuan pengetahuan sebelum dan sesudah diberi perlakuan dengan model Kooperatif Tipe Think Pair Share (TPS) di kelas eksperimen dan kelas kontrol. Berdasarkan hasil analisis data pretest diperoleh bahwa data kedua kelas berdistribusi normal. Pengujian homogenitas sesudah pemberian perlakuan menunjukkan bahwa seluruh kelas memiliki varian yang homogen.

Setelah dilaksanakan pembelajaran, masing-masing kelas diberi posttest untuk mengetahui hasil pengetahuan belajar siswa. Berdasarkan hasil posttest siswa pada kelompok eksperimen memperoleh nilai rata-rata 81,94 dan siswa kelompok kontrol memperoleh nilai rata-rata 69,75. Hal ini karena model Kooperatif Tipe Think Pair Share (TPS) TPS dapat mengoptimalkan hasil belajar siswa setelah proses pembelajaran dilaksanakan karena saat pelaksanaan pembelajaran berlangsung siswa aktif dalam berpikir. Sesuai dengan yang dikemukakan Lestari dan Yudhanegara (2017:52) "TPS merupakan salah satu tipe pembelajaran kooperatif yang merangsang aktivitas berpikir siswa secara berpasangan dan berbagi pengetahuan kepada siswa lainnya".

Pembelajaran dengan model Kooperatif Tipe Think Pair Share (TPS) diawali dengan siswa berfikir untuk menyelesaikan permasalahan yang diberikan. Pada tahap berfikir ini, siswa diberi waktu untuk memikirkan jawaban dari permasalahan yang telah diberikan. Selanjutnya siswa dipasangkan dengan teman sebelahnya untuk dijadikan sebagai kelompok yang beranggotakan dua orang dalam satu kelompok. Saat duduk berkelompok inilah siswa bisa berdiskusi dengan saling bertukar fikiran tentang jawaban yang mereka dapat. Selanjutnya mereka mempresentasikan hasil diskusinya di depan kelas secara bergantian. Setelah semua kelompok selesai maka guru memberikan tanggapan terhadap hasil kerja mereka.

Sesuai dengan pendapat Taufik, Taufina dan Muhammadi (2012) bahwa langkahlangkah model pembelajaran Think Pair Share (TPS) adalah: 1) Think, dimana siswa diminta untuk berfikir secara mandiri tentang materi/permasalahan yang diberikan oleh guru, 2) Pair, siswa diminta untuk berpasangan dengan teman sebelahnya (kelompok 2 orang) dan saling berbagi fikirannya masing-masing, dan 3) Share, guru meminta pasangan-pasangan tersebut untuk membagikan hasil diskusinya di depan kelas.

Pembelajaran di kelas kontrol menggunakan pembelajaran konvensional. Pelaksanaan pada pembelajaran di kelas kontrol ini didominasi oleh guru sedangkan siswa hanya menerima materi yang dijelaskan oleh guru. Pembelajaran di kelas kontrol yang menggunakan pembelajaran konvensional mengakibatkan siswa menjadi jenuh dan siswa menjadi pasif dalam pembelajaran di kelas karena hanya sedikit siswa yang mengeluarkan pendapatnya. Hal ini menunjukkan bahwa siswa di kelas kontrol kurang aktif dibandingkan siswa di kelas eksperimen dalam proses pembelajaran, sehingga berdampak pada hasil belajar siswa di kelas kontrol lebih rendah dari hasil belajar siswa di kelas eksperimen.

Berdasarkan hasil analisis data posttest diperoleh bahwa hasil belajar kedua kelompok berdistribusi normal dan memiliki varian yang homogen. Pengujian hipotesis pada penelitian ini dilakukan dengan Uji-t. Berdasarkan uji t yang telah dilakukan diperoleh thitung 
sebesar 3,51 dan tabel pada taraf kepercayaan $95 \%(\alpha=0.05)$ sebesar 2,028 . Sehingga $t_{\text {hitung }}>t_{\text {tabel }}(3,51>2,028)$, sehingga $\mathrm{H}_{0}$ ditolak dan $\mathrm{H}_{1}$ diterima dan dapat disimpulkan bahwa penelitian ini dapat memberikan pengaruh yang signifikan terhadap hasil belajar siswa. Berdasarkan hasil pengujian hipotesis dapat diketahui bahwa terdapat pengaruh yang signifikan penggunaan model Kooperatif Tipe Think Pair Share (TPS) terhadap hasil belajar siswa pada pembelajaran tematik terpadu kelas V SDN Gugus III Kecamatan Ranah Pesisir.

\section{SIMPULAN}

Berdasarkan hasil analisis data penelitian dan pembahasan dapat disimpulkan bahwa hasil belajar siswa yang diajarkan menggunakan model Think Pair Share (TPS) lebih tinggi dibandingkan dengan hasil belajar siswa yang diajarkan menggunakan pembelajaran konvensional pada pembelajaran tematik terpadu tema 4 subtema 1 pembelajaran 3 dan 4 di kelas V SDN 05 Koto VIII Mudik dan SDN 02 Koto Nan IV. Hal tersebut dibuktikan dari hasil $t$-test dengan taraf signifikansi 5\% (derajat kepercayaan 95\%) diperoleh thitung $>t_{\text {tabel }}$ yaitu $3,51>2,02$. Nilai $t_{\text {hitung }}>t_{\text {tabel }}$ menunjukkan hasil belajar pada pembelajaran tematik terpadu tema 4 subtema 1 pembelajaran 3 dan 4 kedua kelas berbeda secara signifikan.

Hal tersebut juga didukung dari perbedaan nilai rata-rata setelah pelaksanaan pembelajaran kelas eksperimen dan kelas kontrol. Kelas eksperimen menerapkan model kooperatif tipe Think Pair Share (TPS) pada pembelajaran tematik terpadu tema 4 subtema 1 pembelajaran 3 dan 4 memiliki rata-rata nilai posttest sebesar 81,94 sedangkan kelas kontrol yang menerapkan pembelajaran konvensional memiliki rata-rata nilai posttest sebesar 69,75. Sehingga dapat disimpulkan bahwa model kooperatif tipe Think Pair Share (TPS) berpengaruh signifikan terhadap hasil belajar siswa pada pembelajaran tematik terpadu di kelas V SDN Gugus III kecamatan Ranah Pesisir.

Berdasarkan hasil dari penelitian yang telah peneliti uraikan, maka dapat dikemukakan beberapa saran sebagai berikut: 1) Diharapkan kepada guru untuk dapat mencoba melakukan model mengajar yang bervariasi dalam pembelajaran tematik terpadu diantaranya menerapkan model Kooperatif Tipe Think Pair Share (TPS) dalam proses pembelajaran, 2) Bagi kepala sekolah sebagai informasi dalam pembina personil guru dalam memberikan sumbangan yang positif untuk perbaikan proses pembelajaran, 3) Penelitian ini hanya meneliti hasil belajar siswa pada Tema 4 Subtema 1 Pembelajaran 3 dan 4 menggunakan model Kooperatif Tipe Think Pair Share (TPS) dan pembelajaran konvensional. Untuk itu, disarankan pada peneliti selanjutnya untuk meneliti aspek-aspek lainnya, 4) Bagi peneliti yang lain diharapkan mengadakan penelitian lanjutan, untuk dapat dicobakan dengan meteri-materi lain yang dirasakan cocok untuk diajarkan dengan model pembelajaran Kooperatif Tipe Think Pair Share (TPS).

\section{DAFTAR PUSTAKA}

Afandi, Muhammad., Chamalah, E., \& Wardani, O.P.. (2013). Model dan Metode di Sekolah. Semarang: Sultan Agung Press

Arikunto. (2014). Prosedur Penelitian Suatu Pendekatan Praktik. Jakarta: Rineka Cipta

Astimar, N., \& Indrawati, T. (2014). PEDAGOGI / Jurnal IImiah IImu Pendidikan Volume XIV Pembelajaran No.2 November 2014. XIV(2), 88-97.

Lestari, K. E., \& Yudhanegara, M. R. (2017). Penelitian Pendidikan Matematika. Bandung: PT Refika Aditama.

Reinita, dan Delsa. A. (2019). Pengaruh Penggunaan Model Kooperatif. Journal of Chemical Information and Modeling, 53(9), 1689-1699. https://doi.org/10.1017/CBO9781107415324.004

Reinita, Miaz, Y., \& Waldi, A. (2019). The effect of jurisprudential inquiry model on civics learning outcomes of elementary students. Journal of Advanced Research in Dynamical and Control Systems, 11(7), 788-794. 
Reinita, R. (2019). Designing Civics Literacy Learning to Promote Elementary Students to Become Good Citizens. 178(July 2018), 276-281. https://doi.org/10.2991/icoie18.2019.62

Reinita, Suarman, F., \& Sakdiyah, H. (2020). Mind mapping effect on the students achievement in civic education for elementary school students. Parikh 2016. https://doi.org/10.4108/eai.11-12-2019.2290898

Shoimin, A. (2014). 68 Model Pembelajaran Inovatif dalam Kurikulum 2013. Yogyakarta: ArRuzz Media.

Taufik, Taufina dan Muhammadi. (2012). Mozaik Pembelajaran Inovatif. Padang: Sukabina Press. 